\title{
LEISHMANIA MEXICANA IN DIDELPHIS MARSUPIALIS AURITA IN SÃO PAULO STATE, BRAZIL
}

\author{
E. L. A. YOShIDA (1), F. M. A. CORReA (1), R. S. PACHECo (2), H. MOMEN (2) and
}

\author{
G. GRIMALDI Jr. (3)
}

A leishmania parasite was isolated from Didelphis marsupialis aurita trapped in the municipality of Conchas in the state of São Paulo (YOSHIDA et al. 1979, Rev. Inst. Med. trop. São Paulo 21 (2): 110-113). This isolate has now been analysed at the genotypic and phenotypic levels. Zymodeme analysis using agarose gel electrophoresis and 6 enzymes (ALAT, ASAT, MDH, G6PDH, GPI \& PGM) showed that the isolate was similar to a reference strains of L.m. mexicana from Belize. Serodeme analysis using a panel of L.m. mexicana species and subspecies specific monoclonal antibodies in a radioimmune binding assay confirmed this parasite as a member of the L. mexicana complex. However for the first time subspecies specific monoclonal antibodies of both L.m. mexicana and L.m. amazonensis crossreacted with the isolate. In view of this result we decided to investigate the isolate using schizodeme analysis. The restriction enzyme profile the endonucleases MspI and BspRI showed a profile intermediate between those produced by reference strains of L.m. mexicana and L.m. amazonensis. Furthermore using radioactive DNA probes of these two subspecies and the bidirectional Southern blot technique some hybridization was shown with the L.m. mexicana DNA indicating a degree of homology. We therefore provisionally designate the identity of the parasite as L. mexicana ssp.

\section{RESUIMO}

Leishmania mexicana em Didelphis marsupialis aurita no Estado de São Paulo, Brasil

Foi identificada pela primeira vez a pre sença de L. mexicana em Didelphis marsupialis aurita, no Estado de São Paulo - Município de Conchas, através de caracterização bioquímica.

Recebido para publicação em 8/1/1985.

(1) Departamento de Parasitologia - IBBMA, UNESP, Botucatu, SP, Brasil

(2) Departamento de Bioquímica e Biologia Molecular - FIOCRUZ, RJ

(3) Centro de Microscopia Eletrônica - FIOCRUZ, RJ 